\title{
Does capital structure affect the differences in the financial performance of small enterprises?
}

\author{
Aleksandra Stoiljković \\ University of Novi Sad, Faculty of Economics in Subotica, Subotica, Serbia \\ Slavica Tomić \\ University of Novi Sad, Faculty of Economics in Subotica, Subotica, Serbia \\ Ozren Uzelac \\ University of Novi Sad, Faculty of Economics in Subotica, Subotica, Serbia
}

\begin{abstract}
Capital structure refers to the combination of debt and equity that the company uses to finance overall operations and growth. One of the most common problems of small enterprises is difficult access to various sources of financing, which is certainly reflected in their capital structure. Deciding on capital structure is one of the most important activities in the company, given that it significantly determines the performance of the company, but also the competitiveness and sustainability of the business. The aim of the study was to investigate whether there is a significant difference in financial performance between enterprises belonging to different leverage levels. Financial leverage was calculated by dividing total debts to total assets and based on leverage the companies are divided into 3 groups. Using ANOVA analysis, we found that the only difference in financial performance indicators was observed with NPM (but with a small effect size: eta square $=0.0470$ ), whereas no statistically significant difference was observed between the groups in the ROE and ROA indicators.
\end{abstract}

Keywords

Capital structure, financial performance, leverage, small enterprises.

\section{Introduction}

"Capital structure is essentially concerned with how a firm finances its overall operations and progress by using different sources of funds" (Martinez, Scherger \& Guercio, 2019, p. 106). Deciding on capital structure is one of the most important issues, given that capital structure largely determines the future performance of the company, and as Trif, Dutu \& Tuleu (2019) state "Business performance is the primary goal of any type of firm, being a top priority for managers" ( $\mathrm{p}$. 292).

Capital structure decisions are very important for companies, because, in addition to affecting financial performance, it significantly contributes to a company's ability to adapt to a competitive and rapidly changing economic environment
(Norvaisiene, 2012). This issue is especially important when it comes to small enterprises, given that many sources of financing are not available to small enterprises, primarily because of their risk, and that the capital structure of small enterprises differs significantly from the capital structure of large companies (Stoiljković \& Marić, 2021).

The relationship between capital structure and company performance is explained by several theories and supported by empirical research from many countries. In this paper, the authors will try to analyse whether capital structure, measured by leverage level, determines the differences in the financial performance of small enterprises in the Autonomous Province of Vojvodina, Republic of Serbia. 
The largest number of empirical studies on capital structure has been conducted in developed countries, where the most significant theories of capital structure have emerged. It is especially important to look at the results of research from developing countries, and to check whether companies with higher levels of leverage have better financial performance, which is mainly shown by the results of research conducted in developed countries.

\section{Theoretical background and review of previous empirical research}

In order for companies to achieve their goals, it is necessary to have certain resources that they can obtain from different sources. Sources of financing can be viewed from different aspects, such as time period, ownership and others. Sources of short term financing are those whose maturity is less than one year and most often include short-term loans and borrowings, payables, short-term securities issued, etc. Longterm sources of financing are those whose maturity is more than one year and are particularly significant in that they reflect the structure of capital and affect the long-term stability of financing (Erić, Beraha, Đuričin, Kecman \& Jakšić, 2012). Equity involves the use of funds by the business owner while debt capital (borrowing) involves borrowing money from a bank or other lenders. Internal financing includes cash flows generated by the company's existing assets (Damodaran, Klajn \& Popović, 2007). Internal sources of financing can be further differentiated into internal own sources (accumulated profit, depreciated capital, formation of reserves from profit) and internal other sources (formation of reserves for taxes, pensions or retention of amounts for fulfilment of some arrears). External financing includes cash flows generated outside the enterprise, from private sources or financial markets. External financing can be obtained by issuing new debt and equity securities or by issuing hybrids, and in accordance with the above, external sources of financing of the company can be classified into external own sources (equity, permanent deposits, equity of the owner, external reserves) and external sources which include all types of loans and other forms of engaging other people's assets (Damodaran et al., 2007). Also, with regard to external sources of financing there is a distinction between informal and formal sources. Informal sources mean funds raised from family, friends and so-called business angels, while formal sources include bank loans, leasing, trade loans and factoring.

"The structure of the sources of financing of the company indicates the security of the company from the aspect of financial independence" (Mirović, Mijić \& Andrašić, 2018, p. 95). Although companies that finance their activities from predominantly their own sources of financing are characterized by high financial stability, these companies, by limiting the use of borrowed sources of financing, at the same time limit the possibility of increasing the return on invested capital and growth rates. However, it should be noted that in addition to greater potential for development and increasing profitability, the large use of borrowed sources of financing also causes greater financial risk (Norvaisiene, 2012).

Small businesses and entrepreneurs face significant problems in obtaining financing to start a business, as well as to finance business development (Jovin, 2016). According to Paunović \& Novković (2003) the most common obstacles to the use of bank loans in small and medium-sized enterprises are: lack of adequate means of securing loans, lack of documentation on business venture and enterprise, lack of knowledge to present the project to creditors appropriately, orientation of lenders to financing large companies and, consequently, lack of a methodology for evaluating small projects, which makes the evaluation process expensive, especially in relation to small, individual loan amounts, while Michaelas, Chittenden \& Poutziouris (1999) cite higher bankruptcy costs, lower marginal income tax rates and highasymmetry information as reasons why small businesses have low debt levels.

Down (2010) states that small firms have limited access to long-term loans. Bastos \& Nakamura (2009) note that since the internal funds of small enterprises are not sufficient to finance their growth, small enterprises must rely more on short-term debt, given that they are not in a position to acquire long-term debt, such as large companies can, because of their characteristics (based on quotation in Pacheco, 2016, p. 540). Mateev \& Birundu (2013) state that larger companies have much higher leverage ratios compared to small companies.

Cassar (2004) states that it can be relatively more expensive for smaller firms to deal with the problem of information asymmetry, which leads 
to capital constraints for small businesses or causes capital to be available at higher rates, which certainly discourages small businesses from using external financing. It can be concluded that small enterprises find it more difficult to access external sources of financing, especially when it comes to banks, which, due to the underdevelopment of the financial market in Serbia, are the dominant source of obtaining borrowed funds. A study conducted in Pakistan shows similar findings. Khan (2012) found that the costs of external sources of financing are much higher and difficult to obtain due to market inefficiency and information asymmetry, and that the analysed companies are largely financed by short-term debt, while only $9 \%$ of company assets are financed by long-term debt.

There are numerous theories of capital structure, among which, in addition to the basic and most famous Modigliani-Miller theory, Trade-off and Pecking order theory stand out. Trade-off theory (Kraus \& Litzenberger, 1973) suggests that firms choose their capital structure by balancing the benefits and costs of debt. The main benefit of using debt refers to tax savings, while debt costs are mainly including bankruptcy costs. The optimum capital structure is achieved by a balance between tax savings based on debt and bankruptcy costs. Pecking order theory (Myers \& Majluf, 1984) does not consider the optimal relationship between debt and equity, but points out that companies prioritize different sources of financing when composing their capital structure, so companies first decide on internal sources of financing, then resort to borrowing, while finally they decide to issue equity.

Also a very important theory, especially when the focus is on small businesses, is the Growth cycle (Berger \& Udell, 1998). According to this theory, capital structure varies with firm size and age, so in the early stages, when companies are young or small, they are directed to financing from internal and mostly informal sources, commercial loans or through business angels, while companies that move to later stages of growth can access various external sources. As companies get older and larger, they will tend to use more external sources of capital (Berger \& Udell, 1998). The authors conclude that different capital structures are optimal at different points in the cycle.

When it comes to empirical research that focuses on small enterprises, capital structure and its impact on enterprise performance, the research results are different. Analysing the decisions on the capital structure on a sample of small and medium-sized enterprises in Portugal, Sardo \& Serrasqueiro (2017) came to results that are in line with the dynamic Trade-off theory, i.e. the analysed enterprises adjusted the ratio of shortterm and long-term debt to respective target ratios. Deesomsak, Paudial \& Pescetto (2004) analysed companies operating in the Asia-Pacific region and came to results that indicate that only in the case of Malaysia is there a significant and negative relationship between profitability and leverage. The results also show that when profits are high, Malaysian firms prefer to use internal sources of financing, which is in line with the predictions of the Pecking order theory. Results of study by Pacheco (2016) in Portuguese small and medium-sized enterprises are in favour of Pecking order theory. Observing the business life cycle of companies, La Rocca, La Rocca \& Cariola (2011) came to interesting results which show that companies depending on the phase of their business life cycle define a different hierarchy of financial decision-making, so in the early stages, debt is the first choice and fundamental for business activities, which is contrary to the usual assumption, while in the maturity phase, firms rebalance the capital structure, relying more on internal sources, which is consistent with the Pecking order theory.

Mwangi \& Birundu (2015) analysed enterprises in Kenya and came to the results which showed that there was no significant effect of capital structure on the financial performance of the analysed small and medium-sized enterprises. San \& Heng (2011) conducted a study in Malaysia and found that, when it comes to small businesses, only earnings per share (EPS) have a significant relationship with capital structure. Specifically, a negative relationship was found between EPS and debt to capital ratio. A similar research was conducted by Abor (2007) on a sample of small and medium-sized enterprises in Ghana and South Africa. By and large, the results indicate that capital structure, particularly longterm and total debt ratios have a negative impact on company performance. When it comes to short-term debt as well as trade credits, a significant and negative relationship was established with the gross profit margin for both Ghana and South Africa, while looking at longterm debt, a significantly positive relationship with gross profit margin was identified, also for both countries. Capital structure shows a negative 
relationship with return on assets in the case of Ghana, while when it comes to South Africa, the results are not so unambiguous. In South Africa, the results are different, so when it comes to the relationship of the observed measure of performance with short-term debt and trade credit, it is significantly positive, while when it comes to long-term debt and total debt, a significantly negative relationship with return on assets was identified. In the case of Tobin's Q, a statistically significant positive relationship was found with short-term debt and trade credit, while a significant negative relationship was found between observed performance measure and longterm debt, as well as between Tobin's Q and total debt ratio.

Expressing the capital structure of companies in Malaysia with indicators of short-term debt, long-term debt and total debt, Salim \& Yadav (2012) came to results that are typical of developing countries, when it comes to the relationship of these indicators of capital structure with the performance of the enterprise. In most of the company's performance measures (return on assets, return on equity and earnings per share), a negative relationship was found with all analysed indicators of capital structure, while in the case of Tobin's Q, a significantly positive relationship was identified between this indicator and short term debt as well as long term debt. A significant study on a sample of companies from the Republic of Serbia was conducted by Dakić \& Mijić (2020). The authors found, among other things, that debt ratio, as a measure of the extent of a company's leverage, has a significant negative impact on return on assets.

As most empirical research suggests, small enterprises need to be careful when composing their capital structure, especially when it comes to the use of debt, given that a decision on capital structure can affect a firm's performance. It was previously stated that deciding on capital structure is one of the most important activities in the company because in addition to the impact it has on the financial performance of the company, it greatly affects the competitiveness of the company and its survival in the market. Inadequate capital structure leads to high capital costs. High capital costs will cause constraints in investment activities, as not all investment alternatives will respond to increased requests for the expected return on investment. The reduced level of investment also limits the further growth of the company and adversely affects its competitiveness (Norvaisiene, 2012). Similarly, Abbasi, Wang \& Abbasi (2017) point out that small and medium-sized enterprises, which rely excessively on debt financing, increase costs, which can cause financial difficulties for the company and lead the company to bankruptcy.

\section{Methodology}

The research sample consisted of 150 small enterprises operating in the Autonomous Province of Vojvodina, Republic of Serbia. The financial statements of the companies, available on the website of the Business Registers Agency, were used to obtain the necessary data. The research will address the following research question: Are there differences in the financial performance of companies belonging to different levels of leverage?

Financial performance was measured by ROE (return on equity), ROA (return on assets) and NPM (net profit margin). ROE was calculated by dividing net income by total equity, ROA was calculated by dividing net income by average total assets and NPM was calculated by dividing net income by sales.

Capital structure mainly includes long-term sources of financing (equity and long-term debt). Although long-term sources of financing are particularly important because they reflect the capital structure and affect the long-term financing stability, due to the willingness of companies to use short-term financing to finance long-term projects, the use of indicators that include only long-term debt could provide a misleading picture of a firm's risk in relation to financial debt (Damodaran, 2007). Therefore, in a large number of empirical studies, measures involving total debts are used to express capital structure (Abor, 2007; Dakić \& Mijić, 2020; Khan, 2012; Salim \& Yadav, 2012; San \& Heng, 2011).

The use of indicators covering total debts is particularly important for studies conducted in developing countries, because companies from these countries have a very low share of long-term debt in the capital structure, which, according to Klapper, Sarria-Allende \& Sulla (2002) "may be the result of the underdevelopment of the banking sector, poor collateral law and weak collateral registries" (p. 13). Stoiljković \& Tomić (2020) found in the sample of small enterprises in Serbia that the indicator of long-term debt / total assets is $7.32 \%$, while short-term debt / total assets is $34.38 \%$. The authors also report that as many as a 
third of the analysed enterprises do not have longterm debt.

Based on the above, the authors consider it justified to use total debt when expressing capital structure, so capital structure was measured by financial leverage, which was calculated by dividing total debts by total assets.

The aim of the study is to investigate whether there is a significant difference in financial performance between companies belonging to different leverage levels. The research assumption is: There is no significant difference in financial performance among companies with different capital structure.

To test the assumption we calculated leverage level of companies and, in accordance with their leverage level, companies are divided into 3 categories by equal percentiles based on scanned cases. Leverage levels are shown in the Table 1.

Table 1 Leverage levels

\begin{tabular}{l|l}
\hline \multicolumn{2}{c}{ Leverage level } \\
\hline $1=\leq 0.30695$ & low leverage \\
\hline $2=0.30696-0.56680$ & moderate leverage \\
\hline $3=>0.56680$ & high leverage \\
\hline
\end{tabular}

Source: The authors

ANOVA Analysis is applied to investigate if there is significant difference between mean values of the 3 financial performance ratios: ROE, ROA and NPM with 3 groups of leverage levels.

The following hypothesis are tested by the procedure of ANOVA:

$\mathrm{H} 1$ : There is no significant difference between mean of ROE in the 3 groups of leverage.

$\mathrm{H} 2$ : There is no significant difference between mean of ROA in the 3 groups of leverage.

$\mathrm{H} 3$ : There is no significant difference between mean of NPM in the 3 groups of leverage.

The hypotheses were tested using ANOVA Analysis by Statistical Package for the Social Sciences, version 20.

\section{Results and discussion}

All the variables were checked to identify univariate outliers, which represent extreme values that did not conform to the normal frequency distributions and represent unusual cases that were not representative. By analysing the table of descriptive statistics and extreme values we found that variables contain outliers.
After identification of these outliers they were excluded from database, as recommended by Pallant (2009).

One-Way ANOVA investigates if the mean values of the 3 financial performance indices ROE, ROA and NPM - varied significantly with respect to three ordinal leverage levels. The first ratio of financial performance that was tested is ROE. The results are shown in the table 2 .

Table 2 ANOVA: ROE (return on equity)

\begin{tabular}{l|l|l|l|l|l}
\hline & $\begin{array}{l}\text { Sum of } \\
\text { Squares }\end{array}$ & df & $\begin{array}{l}\text { Mean } \\
\text { Square }\end{array}$ & F & Sig. \\
\hline $\begin{array}{l}\text { Between } \\
\text { Groups }\end{array}$ & .017 & 2 & .009 & 1.181 & .310 \\
\hline $\begin{array}{l}\text { Within } \\
\text { Groups }\end{array}$ & .976 & 133 & .007 & & \\
\hline Total & .993 & 135 & \multicolumn{3}{|c}{ Source: The authors }
\end{tabular}

Hypothesis $\mathrm{H} 1$ was accepted at $\alpha=0.05$ indicated by $\mathrm{p}=0,310$ for the $\mathrm{F}(2,133)=1,181$. There is no statistically significant difference between mean of ROE in the 3 groups of leverage.

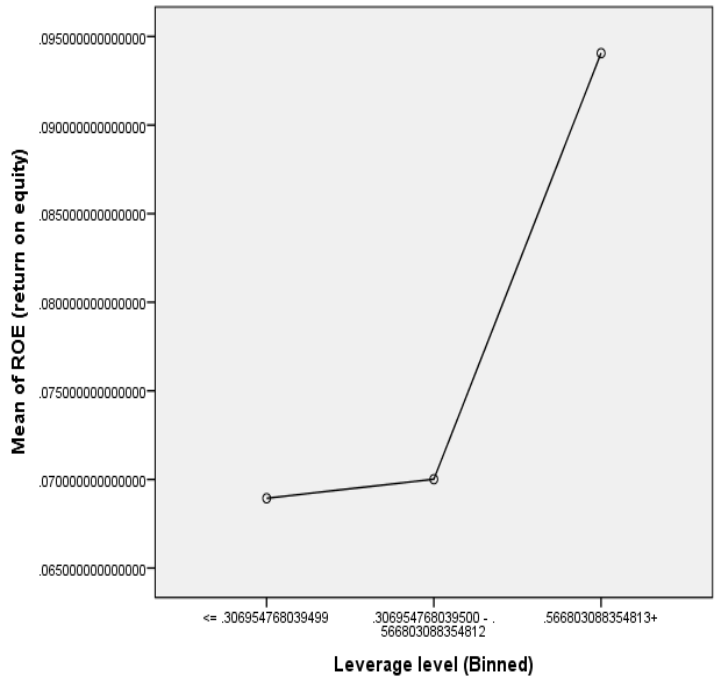

Figure 1 Relationship between mean of ROE and leverage levels Source: The authors

In Figure 1, we can see that the lowest mean of ROE is in the group of low leverage $(<0.30695)$ and the highest mean of ROE is in the group of high leverage $(>0.56680)$. However, if we look at Table 3, we can see that the differences between the means are actually very small. 
Table 3 Descriptive Statistics ROE (return on equity)

\begin{tabular}{l|l|l|l}
\hline & Mean & & Std. Deviation \\
& & & \\
\hline$<=.306954768039499$ & 47 & 068939820497182 & .091992212047923 \\
\hline $.306954768039500-.566803088354812$ & 48 & .070011896587708 & .071061036806440 \\
\hline $.566803088354813+$ & 41 & .094057511753664 & .093439810787051 \\
\hline Total & 136 & .076890445452042 & .085772207451046 \\
\hline
\end{tabular}

Source: The authors

Table 4 ANOVA: ROA (return on assets)

\begin{tabular}{l|l|l|l|l|l}
\hline & $\begin{array}{l}\text { Sum of } \\
\text { Squares }\end{array}$ & df & $\begin{array}{l}\text { Mean } \\
\text { Square }\end{array}$ & F & Sig. \\
\hline $\begin{array}{l}\text { Between } \\
\text { Groups }\end{array}$ & .005 & 2 & .003 & .902 & .408 \\
\hline $\begin{array}{l}\text { Within } \\
\text { Groups }\end{array}$ & .379 & 135 & .003 & & \\
\hline Total & .384 & 137 & \multicolumn{6}{c}{ Source: The authors }
\end{tabular}

Based on the results of the ANOVA analysis, which are shown in Table 4, hypothesis $\mathrm{H}_{2}$ was accepted. There is no statistic significant difference at $\alpha=0.05$ between mean of ROA in the 3 groups of leverage; $F(2,135)=0.902$.

In Figure 2 we can see that the highest mean ROA is at the lowest leverage level and at the highest leverage level, the mean ROA is the lowest.

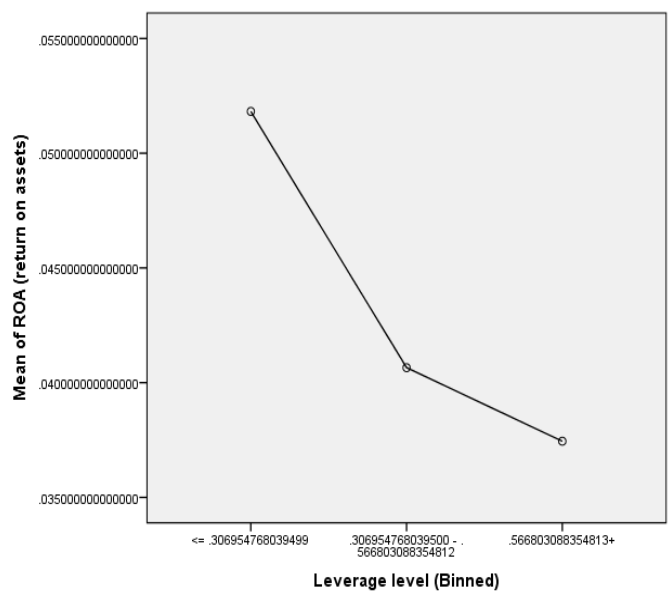

Figure 2 Relationship between mean of ROA and leverage levels Source: The authors

Although the difference in mean values on the diagram appears to be significant, the actual difference in the mean values is very small, as can be seen in the Table 5 .

Table 5 Descriptive Statistics ROA (return on assets)

\begin{tabular}{|c|c|c|c|}
\hline & $\mathbf{N}$ & Mean & Std. Deviation \\
\hline$<=.306954768039499$ & 43 & .051821001388419 & .065864223816591 \\
\hline $.306954768039500-.566803088354812$ & 48 & .040653807324665 & .043085456375192 \\
\hline $.566803088354813+$ & 47 & .037447830701018 & .048694953303918 \\
\hline Total & 138 & .043041549668361 & .052913825050009 \\
\hline
\end{tabular}

Hypothesis $\mathrm{H} 3$ was rejected at $\alpha=0.05$, indicated by $p=0.042$ for the F statistic. There is statistically significant difference between mean of NPM in the 3 groups of leverage: $F(2,132)=$ 3.248 .

Table 6 ANOVA: NPM (net profit margin)

\begin{tabular}{l|l|l|l|l|l}
\hline & $\begin{array}{l}\text { Sum of } \\
\text { Squares }\end{array}$ & df & $\begin{array}{l}\text { Mean } \\
\text { Square }\end{array}$ & F & Sig. \\
\hline $\begin{array}{l}\text { Between } \\
\text { groups }\end{array}$ & .034 & 2 & .017 & 3.248 & .042 \\
\hline $\begin{array}{l}\text { Within } \\
\text { groups }\end{array}$ & .689 & 132 & .005 & & \\
\hline Total & .723 & 134 & \multicolumn{5}{|c}{ Source: The authors }
\end{tabular}

Although a statistically significant difference is confirmed, an eta square must be calculated to determine the effect size:

$$
\text { Eta square }=\frac{\text { Sum of Squares Between Groups }}{\text { Total Sum of Squares }}
$$

$$
\text { Eta square }=0.0470
$$

Based on the value of eta square it was found that, even though the result is statistically significant, the real impact of the difference in mean values of the groups is small. 


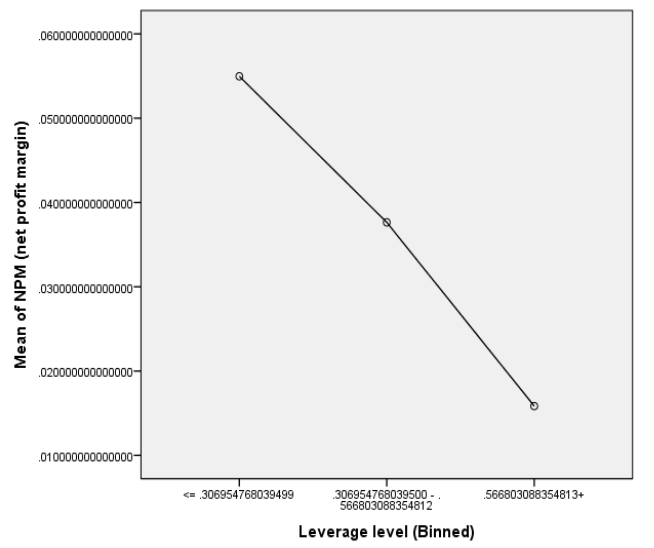

Figure 3 Relationship between mean of NPM and leverage levels

Source: The authors
The highest mean of NPM is present at the lowest leverage level $(<=0.30695)$ and the mean NPM is then systematically decreased with respect to increasing leverage. It can be concluded that the increase in the level of leverage has a negative impact on the financial performance of the company, measured by the indicator of net profit margin, which can also be seen in descriptive statistics shown in Table 7.

Table 7 Descriptive Statistics NPM (net profit margin)

\begin{tabular}{l|l|l|l}
\hline & $\mathbf{N}$ & Mean & Std. Deviation \\
& & & \\
\hline$<=.306954768039499$ & 43 & .054972957772628 & .095980719332439 \\
\hline $.306954768039500-.566803088354812$ & 47 & .037643862879869 & .038045562575542 \\
\hline \hline $.566803088354813+$ & 45 & 015841978858169 & 073107270988242 \\
\hline Total & 135 & .035896205838477 & .073431636036101 \\
\hline
\end{tabular}

Source: The authors

These findings provide evidence to conclude that lower leverage levels are associated with higher NPM levels, and in order to improve their financial performance, small businesses need to reduce the leverage level, i.e. to increase the share of their own sources of financing in the capital structure.

\section{Conclusion}

The study analysed the effect of capital structure on the financial performance of small enterprises in the Autonomous Province of Vojvodina, Republic of Serbia. Financial performance was measured by ROE (return on equity), ROA (return on assets) and NPM (net profit margin), and according to the ratio of total debts to total assets, which was used to express capital structure, companies were divided in 3 groups $(1=$ low leverage, $2=$ moderate leverage and $3=$ high leverage). An attempt was made to answer the question of whether there are differences in financial performance between companies with different levels of leverage. The aim of the study was to investigate using ANOVA analysis if there is significantly difference between mean values of ROE, ROA and NPM with respect to three ordinal leverage levels.

The main findings suggest that there is no statistically significant difference between the indicators of financial performance ROE and ROA in the 3 groups of leverage. We can conclude that leverage levels do not significantly affect the value of ROE and ROA. Besides different groups of leverages, a statistically significant difference is only confirmed in indicator NPM, but when an eta square was calculated to determine the effect of size it was found that even though the result is statistically significant, the real impact of the difference in mean values of the groups is small. Based on the above, it can be concluded that the level of leverage does not significantly influence the financial performance of the company and that the most significant result of the conducted research may indicate that the mean NPM is decreasing with respect to increasing leverage, in other words, companies with lower levels of leverage have higher NPM.

The research results are to some extent in line with the results of similar studies conducted in developing countries, since most of these studies have identified a negative link between the capital structure and financial performance of enterprises. The negative relationship can be explained by the fact that companies in developing countries, due to the underdevelopment of capital markets, are mainly financed by bank loans, especially shortterm debt, which is the dominant source of 
borrowed funds, which is also the case for companies in Serbia. Short-term debt is a relatively expensive source of financing that can expose companies to illiquidity and refinancing risk. Also, companies operating in underdeveloped markets face financial distress and interest rate instability, so inflation and tax rates are of great importance in determining the optimal capital structure of these companies (Karadeniz, Kandir, Balcilar \& Onal, 2009). Very high interest rates can be considered the main stumbling block against modernisation and competitiveness of companies, as Ciutacu, Chivu \& Iorgulescu (2009, p. 743) cite when it comes to Romanian companies.

Small enterprises should be especially careful when it comes to additional borrowing because high indebtedness additionally creates an increase in the risk of default, which certainly affects charging a higher interest rate by the bank to these companies, which ultimately causes the cost of debt to be quite high and, in order not to jeopardize their survival on the market, small businesses should turn to increasing their own sources of financing.sm

\section{References}

Abbasi, W. A., Wang, Z. \& Abbasi, D. A. (2017). Potential sources of financing for small and medium enterprises (SMEs) and role of government in supporting SMEs. Journal of Small Business and Entrepreneurship Development, 5(2), 39-47. https://doi.org/10.15640/jsbed.v5n2a4

Abor, J. (2007). Debt policy and performance of SMEs: Evidence from Ghanaian and South African firms. The Journal of Risk Finance, 8(4), 364-379. https://doi.org/10.1108/15265940710777315

Berger, A. N. \& Udell, G. F. (1998). The economics of small business finance: The roles of private equity and debt markets in the financial growth cycle. Journal of banking \& finance, 22(6-8), 613-673. https://doi.org/10.1016/S0378-4266(98)00038-7

Cassar, G. (2004). The financing of business start-ups. Journal of business venturing, 19(2), 261-283. https://doi.org/10.1016/S0883-9026(03)00029-6

Ciutacu, C., Chivu, L. \& lorgulescu, R. (2009). The global financial crisis: management of deficits and debts. Amfiteatru Economic Journal, 11(Special Number 3), 735-750.

Dakić, S. \& Mijić, K. (2020). Regression analysis of the impact of internal factors on return on assets: a case of meat processing enterprises in Serbia. Strategic Management-International Journal of Strategic Management and Decision Support Systems in Strategic Management, 25(1), 29-34. https://doi.org/10.5937/StraMan2001029D

Damodaran, A., Klajn, J. \& Popović, S. (2007). Korporativne finansije: teorija i praksa. MODUS-Centar za statistička istraživanja i prognoze.
Deesomsak, R., Paudyal, K. \& Pescetto, G. (2004). The determinants of capital structure: evidence from the Asia Pacific region. Journal of multinational financial management, 14(4-5), 387-405. https://doi.org/10.1016/j.mulfin.2004.03.001

Down, S. (2010). Enterprise, entrepreneurship and small business. Sage Publications Ltd.

Erić, D., Beraha, I., Đuričin, S., Kecman, N. \& Jakšić, B. (2012). Finansiranje malih i srednjih preduzeća u Srbiji. Institut ekonomskih nauka: Privredna komora Srbije.

Jovin, S. (2016). Financing obstacles of small enterprisesempirical analysis in the Republic of Serbia. TemeČasopis za Društvene Nauke, 40(3), 1101-1118.

Karadeniz, E., Kandir, S. Y., Balcilar, M. \& Onal, Y. B. (2009). Determinants of capital structure: evidence from Turkish lodging companies. International Journal of Contemporary Hospitality Management, 21(5), 594-609. https://doi.org/10.1108/09596110910967827

Khan, A. G. (2012). The relationship of capital structure decisions with firm performance: A study of the engineering sector of Pakistan. International Journal of Accounting and Financial Reporting, 2(1), 245-262. https://doi.org/10.5296/ijafr.v2i1.1825

Klapper, L. F., Sarria-Allende, V. \& Sulla, V. (2002). Smalland medium-size enterprise financing in Eastern Europe. The World Bank. https://doi.org/10.1596/1813-9450-2933

Kraus, A. \& Litzenberger, R. H. (1973). A state-preference model of optimal financial leverage. The Journal of Finance, 28(4), 911-922. https://doi.org/10.1111/j.1540-6261.1973.tb01415.x

La Rocca, M., La Rocca, T. \& Cariola, A. (2011). Capital structure decisions during a firm's life cycle. Small Business Economics, 37(1), 107-130. https://doi.org/10.1007/s11187-009-9229-z

Myers, S. C. \& Majluf, N. S. (1984). Corporate financing and investment decisions when firms have information that investors do not have. Journal of financial economics, 13(2), 187-221. https://doi.org/10.1016/0304-405X(84)90023-0

Martinez, L. B., Scherger, V. \& Guercio, M. B. (2019). SMEs capital structure: trade-off or pecking order theory: a systematic review. Journal of Small Business and Enterprise Development, 26(1), 105-132. https://doi.org/10.1108/JSBED-12-2017-0387

Mateev, M., Poutziouris, P. \& Ivanov, K. (2013). On the determinants of SME capital structure in Central and Eastern Europe: A dynamic panel analysis. Research in International Business and Finance, 27(1), 28-51. https://doi.org/10.1016/j.ribaf.2012.05.002

Michaelas, N., Chittenden, F. \& Poutziouris, P. (1999). Financial policy and capital structure choice in UK SMEs: Empirical evidence from company panel data. Small business economics, 12(2), 113-130. https://doi.org/10.1023/A:1008010724051

Mirović, V., Mijić, K. \& Andrašić, J. (2018). Corporate performance of agricultural enterprises in AP Vojvodina from the aspect of financing sources. Anali Ekonomskog fakulteta u Subotici, (40), 95-105. https://doi.org/10.5937/AnEkSub1840095M

Mwangi, M. \& Birundu, E. M. (2015). The effect of capital structure on the financial performance of small and medium enterprises in Thika Sub-County, Kenya. International Journal of Humanities and Social Science, 5(1), 151-156. 
Norvaisiene, R. (2012). The impact of capital structure on the performance efficiency of Baltic listed companies. Engineering Economics, 23(5), 505-516. https://doi.org/10.5755/j01.ee.23.5.1979

Pacheco, L. (2016). Capital structure and internationalization: The case of Portuguese industrial SMEs. Research in International Business and Finance, 38, 531-545. https://doi.org/10.1016/j.ribaf.2016.07.014

Pallant, J. (2013). SPSS Survival Manual. McGraw-Hill Education (UK).

Paunović, B. \& Novković, N. (2003). Mogućnosti i uslovi finansiranja malih i srednjih preduzeća. Časopis za procesnu tehniku i energetiku u poljoprivredi/PTEP, 7(12), 12-15

Salim, M. \& Yadav, R. (2012). Capital structure and firm performance: Evidence from Malaysian listed companies. Procedia-Social and Behavioral Sciences, (65), 156-166.

https://doi.org/10.1016/j.sbspro.2012.11.105

San, O. T. \& Heng, T. B. (2011). Capital structure and corporate performance of Malaysian construction sector. International Journal of Humanities and Social Science, 1(2), 28-36.

\section{$\bowtie$ Correspondence}

\section{Ozren Uzelac}

University of Novi Sad, Faculty of Economics in Subotica, Segedinski put 9-11, 24000, Subotica, Serbia

E-mail: ozren.uzelac@ef.uns.ac.rs
Sardo, F. \& Serrasqueiro, Z. (2017). Does dynamic trade-off theory explain Portuguese SME capital structure decisions? Journal of Small Business and Enterprise Development, 24(3), 485-502. https://doi.org/10.1108/JSBED-12-2016-0193

Stoiljković, A. \& Marić, S. (2021). Financing and Success/Performance of Small Businesses in Serbia. Management: Journal of Sustainable Business and Management Solutions in Emerging Economies. Forthcoming articles. https://doi.org/10.7595/management.fon.2020.0022

Stoiljković, A., \& Tomić, S. (2020). Analysis of Small Business Capital Structure. Proceedings of the 25th International Scientific Conference Strategic Management and Decision Support Systems in Strategic Managemen, 279-283. https://doi.org/10.46541/978-86-7233-386-2 34

Trif, S. M., Duțu, C. \& Tuleu, D. L. (2019). Linking CRM capabilities to business performance: a comparison within markets and between products. Management \& Marketing. Challenges for the Knowledge Society, 14(3), 292-303.

https://doi.org/10.2478/mmcks-2019-0021 